\title{
ANALISIS PENGARUH PENDIDIKAN IBU TERHADAP STATUS GIZI BALITA DI PROVINSI KALIMANTAN BARAT
}

\author{
(Influence Analysis of Maternal Education to Under Five Years-old Children \\ In West Kalimantan Province)
}

M Rizal Damanik ${ }^{1 *^{*}}$, Ikeu Ekayanti ${ }^{1}$, dan Didik Hariyadi ${ }^{2}$

\footnotetext{
1* Alamat korespondensi: Departemen Gizi Masyarakat, Fakultas Ekologi Manusia, Institut Pertanian Bogor, Bogor 16680. Telp: 0251-8621258; Fax: 0251-8622276

1 Departemen Gizi Masyarakat, Fakultas Ekologi Manusia, Institut Pertanian Bogor, Bogor 16680.

2 Jurusan Gizi Politeknik Kesehatan Pontianak, Kemeterian Kesehatan Republik Indonesia.
}

\begin{abstract}
The present study aims to analyze of influence maternal education to under five yearsold children in West Kalimantan Province. The study uses Health Research Data Base of West Kalimantan Province in year 2007 with the design of cross-sectional study. The total of 1992 household samples were recruited in the study with criteria having child aged 6 to 59 months. Weight for height, weight for age, and height for age indicators were used to measure child nutritional status. The results showed that Logistic multiple regression analysis showed that maternal education under level of junior high school had 1.28 risk for children to become stunting and 1.27 risk for children to become underweight than maternal education level of above junior high school.
\end{abstract}

Key words: wasting, stunting, maternal education.

\section{PENDAHULUAN}

Gizi merupakan salah satu penentu kualitas Sumber Daya Manusia (SDM). Makanan yang diberikan sehari-hari harus mengandung semua zat gizi sesuai kebutuhan, sehingga menunjang pertumbuhan yang optimal dan dapat mencegah penyakit defisiensi, mencegah keracunan dan juga mencegah timbulnya penyakit yang dapat mengganggu kelangsungan hidup anak (Soekirman, 2000).

Masa bayi dan anak adalah masa mereka mengalami pertumbuhan dan perkembangan yang cepat dan sangat penting sebagai landasan yang menentukan kualitas generasi penerus bangsa (Azwar, 2000).

Status gizi balita sangat dipengaruhi oleh lingkungan sosial terdekat. Di samping itu peran keluarga sangat besar dalam membentuk kepribadian anak. Pola pendidikan yang tepat yang diterapkan oleh orang tua akan sangat membantu anak dalam menghadapi kondisi lingkungan pada masa yang akan datang. Orang tua merupakan tempat bergantung anak-anaknya dan harus memberikan kasih sayang dan perhatian sepenuhnya pada anak hingga remaja.

Penyebab langsung status gizi yaitu makanan anak dan penyakit infeksi yang mungkin diderita anak. Penyebab gizi kurang tidak ha- nya disebabkan makanan yang kurang tetapi juga karena penyakit. Anak yang mendapat makanan yang baik tetapi sering menderita penyakit infeksi dapat menderita kurang gizi. Demikian pula pada anak yang makannya tidak cukup baik, maka daya tahan tubuh akan melemah dan mudah terserang penyakit, sehingga makanan dan penyakit merupakan penyebab kurang gizi (Supariasa et. al. 2002).

Penelitian tentang pengaruh pendidikan ibu terhadap status gizi balita khususnya di Provinsi Kalimantan Barat belum pernah dilakukan. Hasil RISKESDAS di Provinsi Kalimantan Barat 2007, ditemukan data sebagai berikut: prevalensi balita dengan gizi kurang dan buruk (underweight) berdasar berat badan menurut umur $(\mathrm{BB} / \mathrm{U})$ sebesar $22.6 \%$, status pendek dan sangat pendek (stunting) berdasar tinggi badan menurut umur (TB/U) mencapai $36.8 \%$, kurus dan sangat kurus (wasting) berdasar berat badan menurut tinggi badan (BB/TB) sebanyak $17.3 \%$, sedangkan prevalensi gizi lebih berdasar $\mathrm{BB} / \mathrm{U}$ didapat sebesar $5 \%$ dan berdasarkan BB/TB 14\%. Prevallensi Stunting sangat tinggi dibandingkan dengan indikator status gizi balita yang lain. Todaro \& Smith (2009) mengemukakan bahwa status pendek merupakan salah satu faktor penting dalam peningkatan produktifitas manusia. 
Peneliti ingin melihat apakah ada pengaruh pendidikan ibu terhadap status gizi balita di Provinsi Kalimantan Barat.

\section{METODE PENELITIAN}

\section{Desain, Tempat, dan Waktu}

Jenis penelitian ini adalah penelitian observasional menggunakan data sekunder hasil Riskesdas 2007 dengan desain cross sectional, dimana pengukuran outcome dan potential predictor dilakukan secara simultan pada waktu yang bersamaan (Aswin, 1997) sesuai dengan desain Riskesdas 2007 di Provinsi Kalimantan Barat. Wilayah penelitian di Provinsi Kalimantan Barat yang dilaksanakan pada bulan Januari 2010 sampai dengan Maret 2010.

\section{Jumlah dan Cara Penarikan Sampel}

Populasi dalam Riskesdas Provinsi Kalimantan Barat 2007 adalah seluruh rumah tangga di wilayah Provinsi Kalimantan Barat. Sampel adalah rumah tangga dan anggota rumah tangga yang diambil dengan menggunakan metodologi penghitungan dan cara penarikan sampel identik dengan two stage sampling yang digunakan dalam SUSENAS 2007. Setiap kabupaten/kota yang masuk dalam kerangka sampel kabupaten/kota, diambil sejumlah blok sensus yang proporsional terhadap jumlah rumah tangga di kabupaten/kota tersebut. Jumlah rumah tangga pada sebuah kabupaten/ kota diambil dengan metode probability proportional to size. Setiap blok sensus terpilih kemudian dipilih 16 (enam belas) rumah tangga secara acak sederhana.

Jumlah rumah tangga yang mempunyai balita berdasarkan data yang diperoleh dari Badan Penelitian dan Pengembangan Kesehatan (Balitbangkes) Depkes RI sebanyak 2.375 rumah tangga. Selanjutnya ditetapkan sampel rumah tangga dengan kriteria inklusi adalah rumah tangga yang mempunyai balita umur 6 59 bulan, mempunyai data BB dan TB dengan cut off point sesuai indikator z-score status gizi $\mathrm{BB} / \mathrm{TB}, \mathrm{TB} / \mathrm{U}$ dan $\mathrm{BB} / \mathrm{U}$ pada WHO (World Health Organization) Anthro 2009 dan mempunyai data sosial ekonomi dan pendidikan orang tua, sehingga jumlah sampel diperoleh sebanyak 1992 rumah tangga balita (Gambar 1).

\section{Pengolahan dan Analisis Data}

Data perilaku KADARZI rumah tangga dikategori baik dan kurang baik menggunakan indikator yang dipakai Depkes (2007) dengan empat dari lima indikator pengukuran. Data Status gizi menggunakan kategori baku antropometri WHO (2006) yang didasarkan pada nilai $z$-score berdasarkan BB/TB, TB/U dan $B B / U$. Data infeksi yang diambil adalah data infeksi saluran pernapasan atas (ISPA), diare, demam thypoid, malaria, campak dan demam berdarah. Penilaian menggunakan kuesioner dengan menanyakan pernah menderita atau pernah didiagnosa oleh tenaga medis menderita. Selanjutnya dikategorikan pernah atau tidak pernah menderita satu atau lebih penyakit ISPA, diare, demam thypoid, malaria, campak atau demam berdarah. Data konsumsi gizi akan didasarkan pada kelompok zat gizi energi, protein dan vitamin A sesuai dengan ketersediaan data Riskesdas 2007. Selanjutnya kebutuhan masing-masing zat gizi dihitung berdasarkan kelompok umur menggunakan standar AKG tahun 2004.

Analisis data hasil penelitian disajikan dalam bentuk deskriptif dan inferensial. Analisis univariat untuk melihat distribusi frekuensi masing-masing variabel penelitian. Analisis bivariat digunakan untuk mengetahui hubungan antara masing-masing variabel independen dan variabel dependen. Uji kemaknan digunakan metode Chi-Square $\left(\chi^{2}\right)$ (Selvin, 1996). Analisis multivariat menggunakan regresi logistik ganda. Kriteria kemaknaan statistik yang dipakai adalah $\rho<0.05$. Nilai confidence interval $(\mathrm{Cl})$ ditetapkan 95\%. Pengolahan dan analisis data masing-masing menggunakan software Microsoft Office Excell 2007 dan software SPSS

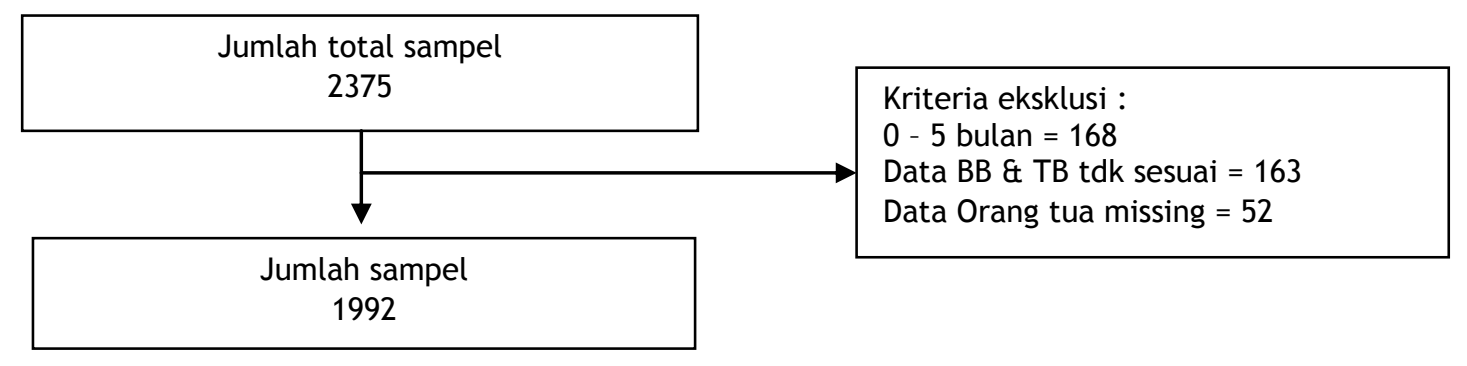

Gambar 1. Skema Jumlah dan Pengambilan Sampel 
(Statistic Program for Social Science) for windows versi 16.0 tahun 2007. Penentuan nilai $z$ score berdasarkan $\mathrm{BB} / \mathrm{TB}, \mathrm{BB} / \mathrm{U}$ dan $\mathrm{TB} / \mathrm{U}$ menggunakan software Anthro WHO versi 3.0.1 tahun 2009.

\section{HASIL DAN PEMBAHASAN}

\section{Karakteristik Sampel}

Rata-rata umur balita dalam penelitian ini adalah $30.9 \pm 14.6$ bulan dengan kelompok umur tertinggi antara 25 - 43 bulan (37.9\%) dan jenis kelamin laki-laki $52.2 \%$. Berat badan rata-rata $12.1 \pm 3.7 \mathrm{~kg}$ dan tinggi badan $86.6 \pm$ $12.4 \mathrm{~cm}$. Prevalensi status gizi balita $(6-59$ bulan) yang diukur berdasarkan indeks $B B / T B$, $\mathrm{BB} / \mathrm{U}$ dan $\mathrm{TB} / \mathrm{U}$ menunjukkan bahwa sebagian besar balita mempunyai status gizi normal dan baik dibandingkan dengan kategori status gizi yang lain, masing-masing sebesar 70.4\%, 73.2\% dan 56.5\% (Tabel 1). Berdasarkan kriteria masalah gizi yang ditetapkan Depkes (2009) berdasarkan WHO, Kalimantan Barat menghadapi masalah gizi akut-kronis dengan karakteristik masalah gizi sebagi berikut: prevalensi balita wasting mencapai $17.0 \%$ (> 5\%), balita stunting mencapai $43.4 \%$ (> 20\%) dan balita status gizi underweight sebesar $24.1 \%$ (> 10\%) dengan prevalensi status infeksi balita di Kalimantan Barat menyebar antara yang infeksi dan tidak infeksi masing-masing $47.8 \%$ dan $52.2 \%$.

Infeksi merupakan salah satu faktor penyebab langsung status gizi balita disamping konsumsi. Pada masa anak-anak yang sedang tumbuh umumnya akan mengalami lebih dari 100 macam infeksi sebelum mencapai masa dewasa. Kejadian ini akan lebih buruk jika terjadi pada daerah miskin, sanitasi yang buruk dan daerah dengan masalah gizi (Linder, 1992).

Sebaran status infeksi berdasarkan kelompok umur kejadian infeksi tertinggi terjadi pada anak umur 44 - 59 bulan mencapai 56.8\%, secara proporsional hampir sama dengan anak umur 25 - 43 bulan sebesar $51.2 \%$. Data ini menunjukkan kecenderungan kejadian infeksi pada anak 6 - 59 bulan, semakin bertambah umur semakin tinggi (Gambar 2). Penelitian ini sejalan dengan laporan Riskesda Provinsi Kalimantan Barat 2007 yang menunjukkan adanya peningkatan kejadian ISPA, TB Paru, Campak dan Tifoid pada umur 1 - 4 tahun dibanding umur < 1 tahun.

Konsumsi energi dan vitamin A balita sebagian besar masih defisit (66.5\% dan 68.2\%) dibandingkan dengan konsumsi protein yang sebagian besar $(66.9 \%)$ sudah baik. Zat gizi protein merupakan salah satu zat gizi penting terutama pada masa pertumbuhan dan perkembangan balita. Kalimantan Barat merupakan salah satu wilayah yang kaya akan hasil laut dan sungai, sehingga dimungkinkan kon sumsi protein balita lebih baik dari konsumsi energi dan vitamin $\mathrm{A}$.

Sebaran status infeksi berdasarkan kelompok umur kejadian infeksi tertinggi terjadi pada anak umur 44 - 59 bulan mencapai 56.8\%, secara proporsional hampir sama dengan anak umur 25 - 43 bulan sebesar $51.2 \%$. Data ini menunjukkan kecenderungan kejadian infeksi pada anak 6 - 59 bulan, semakin bertambah umur semakin tinggi (Gambar 8). Penelitian ini sejalan dengan laporan Riskesda Provinsi Kalimantan Barat 2007 yang menunjukkan adanya peningkatan kejadian ISPA, TB Paru, Campak dan Tifoid pada umur 1 - 4 tahun dibanding umur < 1 tahun.

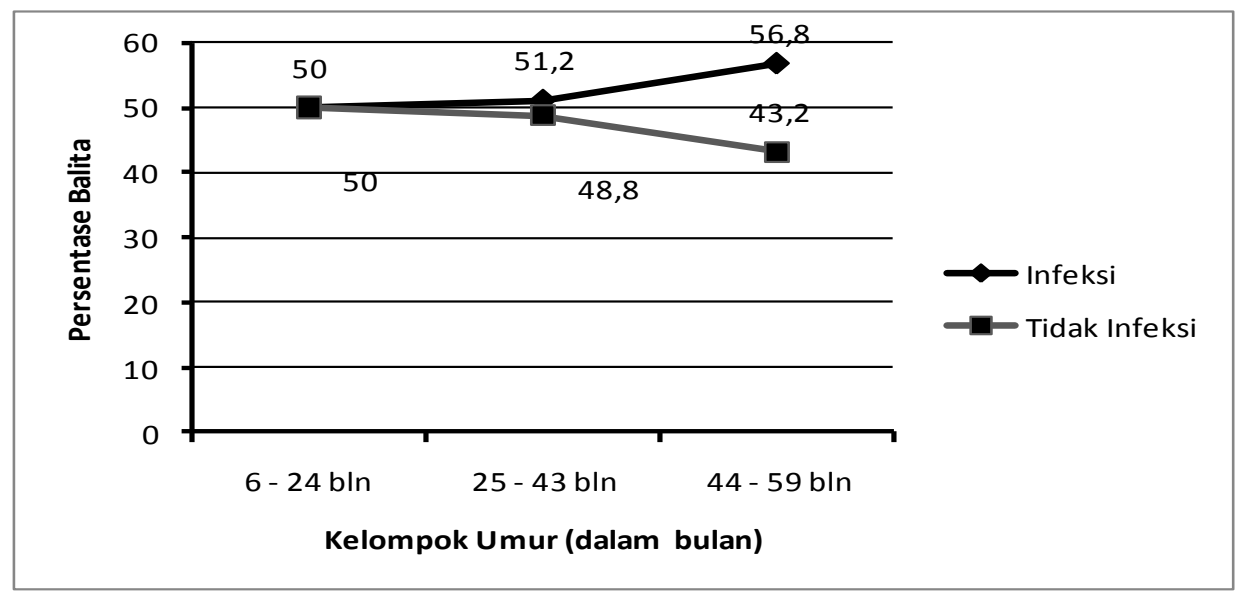

Gambar 2. Persentase Sebaran Infeksi Balita berdasarkan Kelompok Umur 
Tabel 1. Sebaran Karakteristik Sampel

\begin{tabular}{|c|c|c|}
\hline & n (\%) & Mean \pm SD \\
\hline \multicolumn{3}{|l|}{ Balita $(n=1992)$} \\
\hline Umur (bulan) & & $31.5 \pm 14.6$ \\
\hline $6-24$ & 704 (35.3) & \\
\hline $25-43$ & 777 (39.0) & \\
\hline $44-59$ & $511(25.7)$ & \\
\hline \multicolumn{3}{|l|}{ Jenis Kelamin } \\
\hline Laki-laki & $1026(51.5)$ & \\
\hline Perempuan & $966(48.5)$ & \\
\hline Berat Badan (BB) & & $11.7 \pm 3.2$ \\
\hline Tinggi Badan (TB) & & $86.4 \pm 12.4$ \\
\hline Status Gizi (BB/TB) & & $-0.29 \pm 1.97$ \\
\hline Normal & $1403(70.4)$ & \\
\hline Kurus & $170(8.5)$ & \\
\hline Sangat Kurus & $169(8.5)$ & \\
\hline Gemuk & $250(12.6)$ & \\
\hline Status Gizi (BB/U) & & $-1.09 \pm 1.46$ \\
\hline Baik & 1459 (73.2) & \\
\hline Kurang & $340(17.1)$ & \\
\hline Buruk & $140(7.0)$ & \\
\hline Lebih & $54(2.7)$ & \\
\hline Status Gizi (TB/U) & & $-1.34 \pm 2.44$ \\
\hline Normal & $1126(56.5)$ & \\
\hline Pendek & 389 (19.5) & \\
\hline Sangat Pendek & 477 (23.9) & \\
\hline \multicolumn{3}{|l|}{ Status Infeksi } \\
\hline Infeksi & $952(47.8)$ & \\
\hline Tidak Infeksi & $1040(52.2)$ & \\
\hline \multicolumn{3}{|l|}{ Konsumsi $(\mathrm{N}=1879)$} \\
\hline Energi & & $675.6 \pm 676.2$ \\
\hline Baik ( $\geq 100 \%$ AKG) & $341(17.1)$ & \\
\hline Sedang (80 - 90\% AKG) & $129(6.5)$ & \\
\hline Kurang (70 - 79.9\% AKG) & $85(4.3)$ & \\
\hline Defisit (< 70\%AKG) & $1324(66.5)$ & \\
\hline Protein & & $51.1 \pm 29.3$ \\
\hline Baik ( $\geq 100 \%$ AKG) & $1333(66.9)$ & \\
\hline Sedang ( $80-90 \%$ AKG) & $73(3.7)$ & \\
\hline Kurang (70 - 79.9\% AKG) & $38(1.9)$ & \\
\hline Defisit $(<70 \% A K G)$ & $435(21.8)$ & \\
\hline Vitamin A & & $250.9 \pm 216.5)$ \\
\hline Baik ( $\geq 100 \%$ AKG) & $335(16.8)$ & \\
\hline Sedang (80 - 90\% AKG) & $125(6.3)$ & \\
\hline Kurang (70 - 79.9\% AKG) & $61(3.1)$ & \\
\hline Defisit $(<70 \% A K G)$ & $1358(68.2)$ & \\
\hline \multicolumn{3}{|l|}{ Orang Tua $(n=1992)$} \\
\hline \multicolumn{3}{|l|}{ Pendidikan Ayah } \\
\hline$\leq \mathrm{SD}$ & $1213(60.9)$ & \\
\hline SMP & $348(17.5)$ & \\
\hline$\geq$ SMA & $431(21.6)$ & \\
\hline \multicolumn{3}{|l|}{ Pendidikan Ibu } \\
\hline$\leq S D$ & $1248(62.7)$ & \\
\hline SMP & $354(17.8)$ & \\
\hline$\geq$ SMA & $390(19.6)$ & \\
\hline Pengeluaran RT & & $925000 \pm 426800$ \\
\hline$\geq$ Rata-rata & $844(42.4)$ & \\
\hline$<$ Rata-rata & $1148(57.6)$ & \\
\hline
\end{tabular}

Konsumsi energi dan vitamin A balita sebagian besar masih defisit (66.5\% dan 68.2\%) dibandingkan dengan konsumsi protein yang sebagian besar $(66.9 \%)$ sudah baik. Protein merupakan salah satu zat gizi penting terutama pada masa pertumbuhan dan perkembangan balita. Kalimantan Barat merupakan salah satu wilayah yang kaya akan hasil laut dan sungai, sehingga dimungkinkan konsumsi protein balita lebih baik dari konsumsi energi dan vitamin $A$. 
Tabel 1 juga menunjukkan bahwa proporsi tingkat pendidikan orang tua balita baik ayah maupun ibu sebagian besar tamat SD atau dibawahnya masing-masing $60.9 \%$ dan $62.7 \%$ sedangkan pengeluaran rumah tangga rata-rata sebesar Rp $925000 \pm 426800$.

\section{Pengaruh Pendidikan Ibu terhadap Status Gizi Balita Indeks BB/TB}

Analisis multivariat digunakan untuk mengetahui pengaruh variabel independen, meliputi status infeksi, konsumsi energi, konsumsi protein, konsumsi vitamin A, pendidikan ayah, pendidikan ibu, pengeluaran rumah tangga, pemanfaatan pelayanan kesehatan, kesehatan lingkungan, penerapan pesan gizi seimbang dan perilaku KADARZI terhadap status gizi indeks $B B / T B, T B / U$ dan $B B / U$ sebagai variabel independent.

Variabel independen penerapan pesan gizi seimbang dan variabel perilaku KADARZI dalam analisis ini tidak menjadi satu kelompok. Hal ini dilakukan dengan pertimbangan bahwa dalam pengukuran antara dua variabel tersebut terdapat dua kriteria yang sama dan data yang diambil dari sumber yang sama, yaitu kriteria makanan seimbang dan penggunaan garam iodium dalam keluarga. Sehingga dalam analisis multivariat variabel independen dibagi menjadi dua kelompok, masing-masing kelompok terdiri dari 10 variabel. Kelompok satu terdiri dari variabel independen status in feksi, konsumsi energi, konsumsi protein, konsumsi vitamin A, pendidikan ayah, pendidikan ibu, pengeluaran rumah tangga, pemanfaatan pelayanan kesehatan, kesehatan lingkungan dan penerapan pesan gizi seimbang, sedangkan kelompok dua terdiri dari variabel independen status infeksi, konsumsi energi, konsumsi protein, konsumsi vitamin A, pendidikan ayah, pendidikan ibu, pengeluaran rumah tangga, pemanfaatan pelayanan kesehatan, kesehatan lingkungan dan perilaku KADARZI.

Analisis menggunakan uji regresi logistik binary. Kelayakan uji masing-masing analisis pengaruh variabel independen terhadap variabel dependen dengan mempertimbangkan pengujian model penuh (omnibus test of model coefficients) dibandingkan dengan model yang hanya dengan konstanta (signifikansi $\rho<0.01$ ). Hosmer and Lemeshow Test juga menjadi pertimbangan kelayakan penggunaan uji dengan melihat nilai chi-square dan nilai signifikansi $\rho>0.05$. Kemampuan prediksi terhadap nilai observasi dengan melihat classification table, dimana model yang mampu memprediksi nilai observasinya dengan baik jika lebih dari $50 \%$. Sementara untuk melihat ada tidaknya multikolinearitas antar variabel independen menggunakan uji matrik korelasi. Variabel yang mempunyai nilai korelasi diatas $0.8 \mathrm{di}$ anggap mempunyai multikolinearitas yang serius dan akan dikeluarkan dari kelompok variabel independen.

Uji regresi logistik pengaruh variable independen terhadap variabel dependen status gizi balita indek $\mathrm{BB} / \mathrm{TB}$ menunjukkan tidak ada pengaruh secara signifikan secara bersamasama, baik pada variabel independen kelompok satu maupun kelompok dua. Selanjutnya tidak dilakukan analisis tahap kedua mengingat bahwa signifikansi statistik yang digunakan dalam penelitian ini adalah $\rho<0.05$. Jika dilihat dari besaran angka signifikansi variabel independen (kelompok satu dan kelompok dua) yang dianalisis, maka pendidikan ayah mempunyai angka signifikansi yang paling rendah dibandingkan dengan variabel independen yang lain, yaitu $\rho=0.15$ ).

Hasil analisis ini memberikan gambaran bahwa semua variabel independen secara bersama-sama tidak berpengaruh terhadap kejadian status gizi balita pada indek BB/TB di Provinsi Kalimantan Barat. Beberapa faktor lain di luar variabel independen pada penelitian ini dimungkinkan sebagai faktor pengaruh terhadap status gizi balita indek BB/TB.

\section{Pengaruh Pendidikan Ibu terhadap Status Gizi Balita Indeks BB/U}

Variabel indepeden kelompok satu dan kelompok dua secara bersama-sama hanya terdapat 3 variabel yang secara signifikan $(\rho<$ 0.05 ) berpengaruh terhadap status gizi balita indek $\mathrm{BB} / \mathrm{U}$, yaitu status infeksi, pendidikan ibu dan kesehatan lingkungan. Hasil analisis menunjukkan bahwa dari 3 variabel yang secara signifikan berpengaruh terhadap status gizi indek $\mathrm{BB} / \mathrm{U}$ diperoleh model yang paling baik dalam memprediksi kejadian masalah status gizi pada indek $\mathrm{BB} / \mathrm{U}$ berturut-turut adalah pendidikan ibu, kesehatan lingkungan dan status infeksi. Pendidikan ibu < SMP dan kesehatan lingkungan yang kurang baik mempunyai peluang risiko yang sama (1.49 kali) terhadap kejadian underweight pada $\mathrm{Cl} 95 \%$ yang berbeda, masing-masing 1.19 - 1.88 dan 1.07 - 2.09, sedangkan balita yang infeksi mempunyai peluang risiko kejadian underweight 1.27 kali $(\mathrm{Cl}$ $95 \% 1.03$ - 1.56) dibandingkan dengan balita yang tidak infeksi (Tabel $2 \& 3$ ).

Pendidikan ibu mempunyai peranan penting dalam mencegah terjadinya masalah 
underweight pada balita. Seorang ibu dapat menentukan bagaimana pola asuh yang akan dipilihnya terutama dalam pemilihan makanan untuk balitanya. Beberapa penelitian sebelumnya juga banyak menemukan bahwa pendidikan ibu berhubungan dengan status gizi balita dan pendidikan ibu mempunyai peran yang penting dalam mengurangi prevalensi masalah gizi (Schultz 1994; Islam et al 1994; Anwar 2006; Rahman et al 2009).

Indikator berat badan dan tinggi badan merupakan salah satu indikator dalam penentuan status gizi. Secara proporsional balita yang normal dan sehat bertambah umur akan diikuti dengan bertambahnya berat badan. Demikian pula dengan bertambahnya tinggi badan bertambah pula berat badannya, sehingga indek $\mathrm{BB} / \mathrm{U}$ (berat badan menurut umur) tidak memberikan indikasi spesifik tentang karakteristik masalah gizi yang diderita apakah tergolong akut, kronis atau akut-kronis. Tetapi indeks $\mathrm{BB} / \mathrm{U}$ memberikan indikasi adanya gangguan gizi.
Hasil analisis ini memberikan gambaran bahwa status gizi balita indek $\mathrm{BB} / \mathrm{U}$ dipengaruhi oleh 3 faktor di Provinsi Kalimantan Barat, yaitu status infeksi, pendidikan ibu dan kesehatan lingkungan. Balita yang menderita infeksi (terutama diare) dapat menurunkan berat badan secara drastis (Linder 1992), sedangkan pendidikan ibu berhubungan dengan pola asuh balita yang merupakan faktor tidak langsung terjadinya underweight bersama-sama dengan kesehatan lingkungan (UNICEF 1998).

Azwar (2004) mengemukakan bahwa pola asuh balita yang kurang memadai dan rendahnya sanitasi lingkungan merupakan salah satu faktor tidak langsung yang mempengaruhi gangguan gizi balita. Demikian pula Soekirman (2001) mengemukakan bahwa perhatian terhadap penyebab utama masalah gizi cenderung mengabaikan faktor lain seperti air bersih, kebersihan lingkungan dan pelayanan kesehatan dasar.

Tabel 2. Hasil Analisis Regresi Logistik Step 2 Pengaruh Variabel Independen (Kelompok Satu) terhadap Variabel Dependen Status Gizi Balita Indek BB/U

\begin{tabular}{|c|c|c|c|}
\hline Variabel Independen & $\begin{array}{c}\text { Odds Ratio } \\
\operatorname{Exp}(B)\end{array}$ & $\begin{array}{c}\text { Cofidence } \\
\text { Interval 95\% }\end{array}$ & Sig. \\
\hline \multicolumn{4}{|c|}{ Variabel Dependen Status Gizi Indeks BB/U $(n=1992)$} \\
\hline Status Infeksi & & & \\
\hline \multicolumn{4}{|l|}{ Tidak Infeksi (0) } \\
\hline Infeksi(1) & 1.27 & $(1.03-1.56)$ & $0.03^{*}$ \\
\hline \multicolumn{4}{|l|}{ Pendidikan Ibu } \\
\hline$<$ SMP (1) & 1.49 & $(1.19-1.88)$ & $0.00^{* *}$ \\
\hline \multicolumn{3}{|l|}{ Kesehatan Lingkungan } & \\
\hline Kurang Baik (1) & 1.49 & $(1.07-2.09)$ & $0.02^{*}$ \\
\hline \multicolumn{4}{|c|}{$\mathrm{R}^{2}$ Nagelkerke $=0.21 ;-2$ Log Likelihood $=2171.30$} \\
\hline
\end{tabular}

"signifikan $\rho<0.05 ;{ }^{* *}$ signifikan $\rho<0.01$

Tabel 3. Hasil Analisis Regresi Logistik Step 2 Pengaruh Variabel Independen (Kelompok Dua) terhadap Variabel Dependen Status Gizi Balita Indek BB/U

\begin{tabular}{|c|c|c|c|}
\hline Variabel Independen & $\begin{array}{l}\text { Odds Ratio } \\
\operatorname{Exp}(B)\end{array}$ & $\begin{array}{c}\text { Cofidence } \\
\text { Interval 95\% }\end{array}$ & Sig. \\
\hline \multicolumn{4}{|c|}{ Variabel Dependen Status Gizi Indeks BB/U $(n=1992)$} \\
\hline \multicolumn{4}{|l|}{ Status Infeksi } \\
\hline \multicolumn{4}{|l|}{ Tidak Infeksi (0) } \\
\hline Infeksi(1) & 1.27 & $(1.03-1.56)$ & $0.03^{*}$ \\
\hline \multicolumn{4}{|l|}{ Pendidikan Ibu } \\
\hline \multicolumn{4}{|l|}{$\geq \operatorname{SMP}(0)$} \\
\hline$<$ SMP (1) & 1.49 & $(1.19-1.88)$ & $0.00^{\mathrm{xx}}$ \\
\hline \multicolumn{4}{|l|}{ Kesehatan Lingkungan } \\
\hline \multicolumn{4}{|l|}{ Baik $(0)$} \\
\hline Kurang Baik (1) & 1.49 & $(1.07-2.09)$ & $0.02^{*}$ \\
\hline \multicolumn{4}{|c|}{$R^{2}$ Nagelkerke $=0.21 ;-2$ Log Likelihood $=2171.30$} \\
\hline
\end{tabular}

* signifikan $\rho<0.05 ;$ " signifikan $\rho<0.01$ 
Kesehatan lingkungan yang kurang baik berpotensi menimbulkan penyakit infeksi yang pada akhirnya akan berdampak pada gangguan masalah gizi. Kejadian ini akan bertambah parah jika didukung oleh rentannya ketahanan tubuh akibat tidak tercukupinya intik vitamin dan mineral tubuh. Gambaran umum konsumsi vitamin A balita yang masih kurang, dimungkinkan turut berperan dalam mempengaruhi kejadian infeksi, mengingat vitamin A juga berfungsi sebagai zat gizi penting dalam kekebalan tubuh terhadap infeksi. Didukung pula dengan tidak berfungsinya protein sebagaimana mestinya akibat kurangnya intik energi dalam tubuh. Akumulasi ini akan berdampak pada kerentanan tubuh yang pada akhirnya status gizi balita terganggu.

\section{Pengaruh Pendidikan Ibu terhadap Status Gizi Balita Indeks TB/U}

Analisis pengaruh variabel independen kelompok satu yang tanpa memasukkan variabel perilaku KADARZI terhadap variabel dependen menunjukkan bahwa ada 3 variabel yang secara signifikan $(\rho<0.05)$ berpengaruh terhadap status gizi indek TB/U. Hasil uji regresi logistik binary menunjukkan bahwa nilai signifikansi paling baik berturut-turut adalah konsumsi energi, kesehatan lingkungan dan pendidikan ibu. Konsumsi energi yang kurang dari 85\% AKG mempunyai peluang risiko stunting 1.37 kali dibandingkan dengan konsumsi energi yang kurang dari $85 \%$ AKG, balita dengan kesehatan lingkungan yang kurang baik mempunyai peluang risiko 1.44 kali stunting dibandingkan dengan balita dengan kesehatan lingkungan yang baik dan pendidikan ibu yang di bawah SMP berpeluang balitanya stunting $1.27 \mathrm{kali}$ dibandingkan dengan balita yang tingkat pendidikan ibunya diatas atau setingkat SMP. Hal ini dapat dilihat dari nilai OR masing-masing 1.37 (Cl 95\% 1.10 - 1.72), 1.44 (Cl 95\% 1.10 - 1.72) dan $1.27(\mathrm{Cl} 95 \% 1.04$ - 1.56). Berbeda dengan hasil analisis pengaruh variabel independen kelompok satu terhadap variabel dependen status gizi balita indek TB/U, pengaruh variabel independen kelompok dua yang memasukkan variabel perilaku KADARZI menunjukkan adanya 4 variabel yang berpengaruh signifikan $(\rho<$ 0.05 ) yaitu konsumsi energi, pendidikan ibu, kesehatan lingkungan dan perilaku KADARZI. Nilai OR masing-masing adalah 1.36 ( $\mathrm{Cl} 95 \%$ 1.06 - 1.74), 1.33 ( Cl 95\% 1.06 - 1.67), 1.46 ( $\mathrm{Cl} 95 \% 1.10$ - 1.93) dan 1.22 ( Cl 95\% 1.01 1.47)(Tabel 4).
Analisis ini (Tabel 5) menunjukkan bahwa konsumsi energi, pendidikan ibu, kesehatan lingkungan dan perilaku KADARZI mempunyai kecenderungan peluang risiko terhadap kejadian stunting yang berbeda-beda. Peluang risiko kejadian stunting pada balita tertinggi pada kesehatan lingkungan yang kurang baik sebesar 1.46 kali, selanjutnya berturut-turut konsumsi energi kurang dari 85\% AKG sebesar 1.36 kali, pendidikan ibu dibawah SMP 1.33 kali dan perilaku KADARZI yang kurang baik sebesar 1.22 kali.

Pendidikan ibu memainkan peranan penting yang menentukan dalam meningkatkan tingkat kecukupan gizi. Prevalensi anak-anak yang terhambat pertumbuhannya (Stunting) yang merupakan indikator dari anak yang kurang gizi, lebih rendah pada ibu dengan tingkat pendidikan yang lebih tinggi dengan tingkat pendapatan berapa pun. Penelitian Alderman \& Garcia (1992) di Pakistan menemukan buktibukti bahwa insiden anak stunting akan menurun dari $63.6 \%$ menjadi $47.1 \%$ jika ibunya mendapatkan pendidikan dasar. Mereka mencatat bahwa dampak ini hampir 10 kali lipat dari yang dihasilkan oleh peningkatan pendapatan per kapita sebesar 10\%, sementara Thomas (1991) mengemukakan bahwa di banyak negara, pendidikan ibu cenderung meningkatkan kesehatan anak perempuan daripada anak lakilaki. Terlepas dari isu gender, jika tinggi badan merupakan salah satu indikator penting dalam mengukur status kesehatan secara umum, maka orang yang lebih tinggi seharusnya mempunyai kesempatan memperoleh penghasilan yang lebih tinggi, sebagaimana temuan Strauss \& Thomas (1998) di Brazil bahwa pria yang lebih tinggi dapat memperoleh penghasilan yang lebih banyak, dimana peningkatan tinggi badan sebanyak $1 \%$ diasosiasikan dengan kenaikan upah sebesar $7 \%$.

Todaro \& Smith (2009) mengemukakan bahwa WHO telah menemukan lima kondisi yang menyebabkan 70\% kematian balita, yaitu infeksi saluran pernapasan akut (ISPA), diare, cacar air, malaria dan kurang gizi. Diperkirakan jika tren ini berlanjut, maka pada tahun 2020 kondisi ini akan menyebabkan 30\% kematian anak di seluruh dunia. Kekurangan gizi adalah sebuah bentuk penyakit dan keberadaannya merupakan faktor penting yang membuat seorang anak mudah tertular penyakit dan meninggal dunia. Dalam banyak hal kematian tidak akan terjadi tanpa kekurangan gizi sebagai faktor penunjangnya. 
Tabel 4. Hasil Analisis Regresi Logistik Step 2 Pengaruh Variabel Independen (Kelompok Satu) terhadap Variabel Dependen Status Gizi Balita Indek TB/U

\begin{tabular}{|c|c|c|c|}
\hline Variabel Independen & $\begin{array}{c}\text { Odds Ratio } \\
\operatorname{Exp}(B)\end{array}$ & $\begin{array}{c}\text { Cofidence Interval } \\
95 \% \\
\end{array}$ & Sig. \\
\hline \multicolumn{4}{|c|}{ Variabel Dependen Status Gizi Indeks TB/U $(n=1992)$} \\
\hline \multicolumn{4}{|l|}{ Konsumsi Energi } \\
\hline \multicolumn{4}{|l|}{$\geq 85 \%$ AKG $(0)$} \\
\hline$<85 \%$ AKG (1) & 1.37 & $(1.10-1.72)$ & $0.01^{*}$ \\
\hline \multicolumn{4}{|l|}{ Pendidikan Ibu } \\
\hline \multicolumn{4}{|l|}{$\geq \operatorname{SMP}(0)$} \\
\hline$<$ SMP (1) & 1.27 & $(1.04-1.56)$ & $0.02^{*}$ \\
\hline \multicolumn{4}{|l|}{ Kesehatan Lingkungan } \\
\hline \multicolumn{4}{|l|}{ Baik $(0)$} \\
\hline Kurang Baik (1) & 1.44 & $(1.10-1.72)$ & $0.01^{*}$ \\
\hline \multicolumn{4}{|c|}{$R^{2}$ Nagelkerke $=0.21 ;-2$ Log Likelihood $=2543.05$} \\
\hline
\end{tabular}

* signifikan $\rho<0.05$

Tabel 5. Hasil Analisis Regresi Logistik Step 2 Pengaruh Variabel Independen (Kelompok Dua) terhadap Variabel Dependen Status Gizi Balita Indek TB/U

\begin{tabular}{|c|c|c|c|}
\hline Variabel Independen & $\begin{array}{l}\text { Odds Ratio } \\
\operatorname{Exp}(B)\end{array}$ & $\begin{array}{c}\text { Cofidence Interval } \\
95 \%\end{array}$ & Sig. \\
\hline \multicolumn{4}{|c|}{ Variabel Dependen Status Gizi Indeks TB/U $(n=1992)$} \\
\hline \multicolumn{4}{|l|}{ Konsumsi Energi } \\
\hline \multicolumn{4}{|l|}{$\geq 85 \%$ AKG $(0)$} \\
\hline$<85 \%$ AKG (1) & 1.40 & $(1.12-1.77)$ & $0.00^{\pi x}$ \\
\hline \multicolumn{4}{|l|}{ Pendidikan Ibu } \\
\hline \multicolumn{4}{|l|}{$\geq \operatorname{SMP}(0)$} \\
\hline$<$ SMP (1) & 1.28 & $(1.05-1.56)$ & $0.01^{*}$ \\
\hline \multicolumn{4}{|l|}{ Kesehatan Lingkungan } \\
\hline \multicolumn{4}{|l|}{ Baik (0) } \\
\hline Kurang Baik (1) & 1.45 & $(1.10-1.91)$ & $0.01^{*}$ \\
\hline \multicolumn{4}{|l|}{ Perilaku Kadarzi } \\
\hline \multicolumn{4}{|l|}{ Baik (0) } \\
\hline Kurang Baik (1) & 1.21 & $(1.01-1.46)$ & $0.04^{*}$ \\
\hline \multicolumn{4}{|c|}{$R^{2}$ Nagelkerke $=0.24 ;-2$ Log Likelihood $=2538.92$} \\
\hline
\end{tabular}

" signifikan $\rho<0.05 ;$ ** signifikan $\rho<0.01$

\section{KESIMPULAN}

Pendidikan ibu mempunyai peranan penting dalam menentukan status gizi balita. Peningkatan pendidikan ibu akan membawa dampak pada investasi sumber daya manusia yang berkualitas, karena dengan peningkatan pendidikan ibu akan meningkatkan status gizi balita yang pada akhirnya dapat meningkatkan peluang kesempatan pendidikan balitanya sebagai modal dasar peningkatan sumber daya manusia yang berkualitas.

\section{DAFTAR PUSTAKA}

Azwar A. 2000. Review Peningkatan Penggunaan ASI dan MP-ASI. Bogor.
Aswin. Soedjono. 1997. Metodologi Penelitian Kedokteran. FK, UGM, Yogyakarta.

[Depkes RI] Departemen Kesehatan Republik Indonesia. 2005. Pedoman Umum Gizi Seimbang (PUGS). Direktorat Bina Gizi Masyarakat, Jakarta

[Depkes RI] Departemen Kesehatan Republik Indonesia. 2007. Keputusan Menteri Kesehatan Republik Indonesia Nomor: 747/ Menkes/SK/VI/2007 Tentang Pedoman Operasional Keluarga Sadar Gizi Di Desa Siaga. Jakarta.

[Depkes RI] Departemen Kesehatan Republik Indonesia. 2008. Laporan Hasil Riset Kesehatan Dasar (Riskesdas) Propinsi Kalimantan Barat Tahun 2007. Badan Pene- 
litian dan Pengembangan Kesehatan Departemen Kesehatan RI, Jakarta.

[Depkes RI] Departemen Kesehatan Republik Indonesia. 2008. Laporan Hasil Riset Kesehatan Dasar (Riskesdas) Indonesia Tahun 2007. Badan Penelitian dan Pengembangan Kesehatan Departemen Kesehatan RI, Jakarta.

[Depkes RI] Departemen Kesehatan Republik Indonesia. 2009. Buku Saku Gizi. Kapankah Masalah Ini Berakhir. Badan Penelitian dan Pengembangan Kesehatan, Jakarta.

Emilia E. 1998. Cara Penilaian Penerapan Pesan-pesan Pedoman Umum Gizi Seimbang (PUGS) pada Pasangan Usia Subur di Kecamatan Ciomas Kabupaten Bogor. Tesis Magister. Sekolah Pascasarjana, IPB, Bogor.

Hardinsyah 1997. Pengembangan Cara Penilaian Penerapan PUGS. Makalah pada PraWidya Karya Nasional Pangan dan Gizi VI. 4 November. Jakarta.

Hardinsyah et al. 1998. Cara Sederhana Penilaian Praktek PUGS Bagi Pasangan Usia Subur. Media dan Gizi Keluarga, XXII (2): $28-35$.

Linder MC. 1992. Biokimia Gizi dan Metabolisme. Dengan Pemakaian secara Klinis. UI Press, Jakarta.
Minarto 2009. Keluarga Sadar Gizi Solusi Atasi Masalah Gizi. http://www.promosikese hatan.com/?act=news\&id=489 [27 Nov 2009]

Nurmayati Y. 2002. Implementasi Program Keluarga Sadar Gizi (KADARZI) Dalam Upaya Meningkatkan Kesejahteraan Keluarga (Studi Kasus Tentang Implementasi Program KADARZI di Kelurahan Betet Kota Kediri). [Abstrak]. Program Pascasarjana. UNS, Surakarta.

Soekirman. 2000. Ilmu Gizi dan Aplikasinya Untuk keluarga dan Masyarakat. Dirjen Pendidikan Tinggi, Jakarta.

Supariasa I, Bakri B, \& Fajar I. 2002. Penilaian Status Gizi. EGC Jakarta.

Selvin S. 1996. Statistical Analysis of Epidemioologic Data. Second Edition. Oxford University Press, Oxford.

Todaro MP \& Smith SC. 2009. Economic Development. Tenth Edition. Pearson Education Inc, Boston, USA

UNICEF. 1998. The State of The World's Children 1998: Focus of Nutrition. Oxford University Press, UK.

Zahraini Y. 2009. Hubungan Status KADARZI dengan Status Gizi Balita 12 - 59 Bulan di Provinsi DI Yogyakarta dan Nusa Tenggara Timur. Skripsi Sarjana. UI, Jakarta. 